\title{
THE ACCEPTANCE OF DIFFERENT TYPES OF MIGRANTS TO SLOVAKIA BASED ON GENDER
}

\author{
Miroslava Bozogáňová, \& Tatiana Pethö \\ The Institute of Social Sciences, Centre of Social and Psychological Sciences, Slovak Academy of \\ Sciences (Slovakia)
}

\begin{abstract}
Schahbasi, Huber and Fieder (2020) found that men are generally more sceptical toward migration than women. The goal of this paper is to analyse the acceptance of different types of migrants to Slovakia based on gender. An experimental vignette methodology (EVM) with a simple experimental design was used - the reason for coming to Slovakia was manipulated. Respondents were randomly assigned to one of three different vignettes. The research sample consisted of 1001 respondents ( $49 \%$ men) aged 17 to 75 years $(\mathrm{M}=44.81 ; \mathrm{SD}=14.92)$. Each vignette describes a different type of migrant according to the reasons for coming to Slovakia, while the word "migrant" was omitted to avoid prejudice. Control group (general description of people coming to Slovakia) - 334 respondents $(51.2 \%$ men), group 1 (people coming for work / study) - 335 respondents $(47.5 \%$ men); and group 2 (people arriving for a threat in their home country) - 332 respondents $(48.2 \%$ men). The data were collected online (panel collection) in the Slovak Republic with the ambition to obtain a representative sample. Respondents were asked if they would accept a person coming to Slovakia from another country for ... a close relative acquired by marriage, a close personal friend, a neighbour living on the same street, co-worker / colleague, citizen of the SR and visitor of the SR, where $1=$ strongly agree $-5=$ strongly disagree. The comparison of respondents using t-test for independent samples showed that there were significant differences between men and women in control group - women had more acceptance for coming people as a close personal friend (Cohen's $d=0.251)$ and less for co-worker / colleague (Cohen's $d=0.224)$ than men. Women from group 1 had also more acceptance in terms of co-worker / colleague (Cohen's $d=0.331$ ) and the visitor of the SR (Cohen's $d=0.276$ ) than men. There were no differences in group 2. For the interpretation of the results, it is necessary to look at the negligible size of the differences between men and women.

Respondents were in the "accepting" part of the scale $(\mathrm{M}=2.31 ; \mathrm{SD}=0.82)$. The results suggest that there are almost none differences in the acceptance of migrants between men and women, regardless of vignette they evaluated in Slovakia. Based on our data is seems, that gender is not the main factor of acceptance rate of different types of migrants.
\end{abstract}

Keywords: Migrants, acceptance, Slovak Republic, vignette.

\section{Introduction}

The construction and social evaluation of different migrant categorizations has been predominantly based on how "perceived forcedness and associated perils" diminish the ability to resist coercive "push" factors for migration (Echterhoff et al., 2020). The difference between category of migrants, foreigners and refugee is not clearly defined in Slovak conditions and on the basis of this ambiguity it performs to form similar attitudes towards migrants in relation to categories of migrants. For example, the difference between political refugees and asylum seekers is economic and political reason. Given that political refugees fleeing persecution have no other choice than to leave their home country, they are likely viewed as deserving of support. By contrast, asylum seekers who primarily migrate for economic reasons may be perceived as less deserving (Hager, \& Veit, 2019).

Ceobanu and Escandell (2010, p. 314) define „immigrants“" as people who come to live in (country) from "abroad". Refugee is characterized as a burden within society. Anderson and Ferguson (2018) points to the fact that are portrayed in society as less than fully human, that repressive policies are being developed to deal with refugees and that, as a result, there is a psychological need to distance oneself from them. Findor, Hruška, Jankovská and Pobudová (2021) state that in Slovakia it is important to point out the terms „refugees“ over „migrants“ in the framework of public opinion and individual 
preferences through testing of intergroup contact hypothesis. Public opinion is formed on the basis of feelings, attitudes, trust, social distance, attitudes to integration, while it would be appropriate to compare the evaluation and experience of participants with individual target groups of migrants.

The assessment of opinion on migrants is related not only to the knowledge of their categorization, but also to the hypothesis of social distance. Social distance is according to Halperin, Canetti and Pedahzur (2007) defined as the extent to which people wish to maintain social distance and avoid increasing levels of intimate contact between themselves and members of different social, racial, ethnic or national groups. Duckitt (2006) states when in-group members feel threatened by out-group members, they may develop negative attitudes towards them. The process of formation of an integrative subjective evaluation of the conflict (threat perception) may be influenced by both contextual factors (conditions) and individual.

Gender differences in the assessment of individual categories of migrants with respect to hypothesis of social distance have not been explicitly the subject of previous research. On the other hand, Cowling, Anderson and Ferguson (2019) found that men showed more negative attitudes towards migrants than women. In particular, it was found that politically conservative, highly nationally identified, less educated, religiously affiliated and male were factors that statistically significant correlated with negative attitudes towards migrants. Previous research by O'Rourke and Sinnott (2006) has found that women tend to be less pro-market in their attitudes than are men and this might lead them to oppose immigration.

From this short theoretical overview, it is clear that the acceptance of different types of migrants based on hypothesis of social distance is influenced by public opinion and attitudes towards migrants. Comprehensive study of this issue is needed to understand the whole process.

\section{Goal}

The goal of this paper is to analyse the acceptance of different types of migrants to Slovakia based of gender. Based on previous research (for example Schahbasi, Huber \& Fieder, 2020) we assume, that women will be more accepting than men.

\section{Methods}

The Social Distance Intensity Score (Mather, Jones, \& Moats, 2017), which combines the Bogardus scale and Likert scale, was used to report whether respondents would relate to members of an out-group (different kinds of migrant) in a variety of ways ranging from "accepting them as close relatives by marriage" to "excluding them from my country." Respondents were asked if they would accept a person coming to Slovakia from another country for ... a close relative acquired by marriage, a close personal friend, a neighbour living on the same street, co-worker / colleague, citizen of the SR and visitor of the SR, where $1=$ strongly agree $-5=$ strongly disagree.

\subsection{Research sample}

The research sample consisted of 1001 respondents $(49 \%$ men) aged 17 to 75 years $(\mathrm{M}=44.81$; $\mathrm{SD}=14.92)$ from Slovakia. Each vignette describes a different type of migrant according to the reasons for coming to Slovakia, while the word "migrant" was omitted to avoid prejudice. Control group (general description of people coming to Slovakia) - 334 respondents (51.2\% men), group 1 (people coming for work / study) - 335 respondents $(47.5 \%$ men); and group 2 (people arriving for a threat in their home country) - 332 respondents $(48.2 \%$ men). The data were collected online (panel collection) in the Slovak Republic with the ambition to obtain a representative sample. Jamovi 1.6.11 was used for data processing. 


\section{Results}

Table 1. Descriptive statistics.

\begin{tabular}{|c|c|c|c|c|c|c|c|}
\hline \multirow{2}{*}{$\begin{array}{l}\text { I would accept a person } \\
\text { coming to Slovakia from } \\
\text { another country for... }\end{array}$} & \multirow[b]{2}{*}{ Group } & \multicolumn{2}{|c|}{ Control group } & \multicolumn{2}{|c|}{ Group 1} & \multicolumn{2}{|c|}{ Group 2} \\
\hline & & Mean & SD & Mean & SD & Mean & SD \\
\hline \multirow{2}{*}{$\begin{array}{l}\ldots \text { a close relative acquired } \\
\text { by marriage }\end{array}$} & men & 2.77 & 1.218 & 2.59 & 1.149 & 2.64 & 1.055 \\
\hline & women & 2.65 & 1.173 & 2.61 & 1.131 & 2.63 & 1.210 \\
\hline \multirow{2}{*}{... a close personal friend } & men & 2.41 & 1.050 & 2.31 & 0.921 & 2.38 & 1.033 \\
\hline & women & 2.16 & 0.936 & 2.25 & 0.941 & 2.26 & 1.068 \\
\hline \multirow{2}{*}{$\begin{array}{l}\ldots \text { a neighbour living on the } \\
\text { same street }\end{array}$} & men & 2.44 & 1.006 & 2.35 & 0.934 & 2.39 & 1.010 \\
\hline & women & 2.29 & 0.894 & 2.17 & 0.929 & 2.24 & 1.031 \\
\hline \multirow{2}{*}{... a co-worker/colleague } & men & 2.29 & 0.950 & 2.26 & 0.889 & 2.17 & 0.992 \\
\hline & women & 2.90 & 0.830 & 1.98 & 0.810 & 2.5 & 0.891 \\
\hline \multirow{2}{*}{$\ldots$ a citizen of the SR } & men & 2.36 & 1.056 & 2.44 & 1.053 & 2.36 & 1.067 \\
\hline & women & 2.37 & 1.013 & 2.27 & 0.988 & 2.35 & 1.074 \\
\hline \multirow{2}{*}{$\ldots$ a visitor of the SR } & men & 2.13 & 1.015 & 2.18 & 0.885 & 2.13 & 1.016 \\
\hline & women & 2.70 & 0.920 & 1.94 & 0.889 & 2.10 & 1.030 \\
\hline
\end{tabular}

Respondents were in the "accepting" part of the scale $(\mathrm{M}=2.31 ; \mathrm{SD}=0.82)$.

Table 2. Student's t-test for independent samples between control group, group 1 and group 2 in acceptance of migrants.

\begin{tabular}{|c|c|c|c|c|c|c|c|}
\hline & & $\mathbf{t}$ & df & $\mathbf{p}$ & $\begin{array}{c}\text { Mean } \\
\text { difference }\end{array}$ & $\begin{array}{c}\text { SE } \\
\text { difference }\end{array}$ & $\begin{array}{c}\text { Effect } \\
\text { Size }\end{array}$ \\
\hline \multirow{6}{*}{ 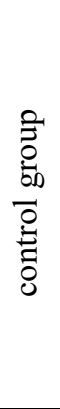 } & $\begin{array}{l}\text {... a close relative } \\
\text { acquired by marriage }\end{array}$ & 0.929 & 332 & 0.354 & 0.122 & 0.131 & 0.102 \\
\hline & $\begin{array}{l}\ldots \text { a close personal } \\
\text { friend }\end{array}$ & 2.292 & 332 & $0.023 *$ & 0.250 & 0.109 & 0.251 \\
\hline & $\begin{array}{l}\text {... a neighbour living } \\
\text { on the same street }\end{array}$ & 1.440 & 332 & 0.151 & 0.150 & 0.104 & 0.158 \\
\hline & $\begin{array}{l}\text {... a co-worker } \\
\text { /colleague }\end{array}$ & 2.049 & 332 & $0.041 *$ & 0.200 & 0.098 & 0.224 \\
\hline & ... a citizen of the SR & -0.103 & 332 & 0.918 & -0.012 & 0.113 & -0.011 \\
\hline & ... a visitor of the SR & 0.518 & 332 & 0.605 & 0.055 & 0.106 & 0.057 \\
\hline \multirow{6}{*}{ 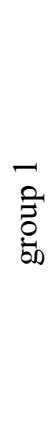 } & $\begin{array}{l}\text {... a close relative } \\
\text { acquired by marriage }\end{array}$ & -0.180 & 333 & 0.857 & -0.022 & 0.125 & -0.020 \\
\hline & $\begin{array}{l}\text {... a close personal } \\
\text { friend }\end{array}$ & 0.571 & 333 & 0.568 & 0.058 & 0.102 & 0.063 \\
\hline & $\begin{array}{l}\text {... a neighbour living } \\
\text { on the same street }\end{array}$ & 1.722 & 333 & 0.086 & 0.176 & 0.102 & 0.188 \\
\hline & $\begin{array}{l}\text {... a co-worker } \\
\text { /colleague }\end{array}$ & 3.028 & 333 & $0.003 * *$ & 0.281 & 0.093 & 0.331 \\
\hline & ... a citizen of the SR & 1.502 & 333 & 0.134 & 0.168 & 0.112 & 0.164 \\
\hline & ... a visitor of the SR & 2.523 & 333 & $0.012 *$ & 0.245 & 0.097 & 0.276 \\
\hline \multirow{6}{*}{$\begin{array}{l}N \\
ٍ \\
0 \\
0\end{array}$} & $\begin{array}{l}\text {... a close relative } \\
\text { acquired by marriage }\end{array}$ & 0.077 & 330 & 0.939 & 0.009 & 0.125 & 0.008 \\
\hline & $\begin{array}{l}\text {... a close personal } \\
\text { friend }\end{array}$ & 1.036 & 330 & 0.301 & 0.120 & 0.116 & 0.114 \\
\hline & $\begin{array}{l}\text {... a neighbour living } \\
\text { on the same street }\end{array}$ & 1.380 & 330 & 0.183 & 0.150 & 0.112 & 0.147 \\
\hline & $\begin{array}{l}\text {... a co-worker } \\
\text { /colleague }\end{array}$ & 1.183 & 330 & 0.238 & 0.122 & 0.103 & 0.130 \\
\hline & $\ldots$ a citizen of the SR & 0.116 & 330 & 0.908 & 0.014 & 0.118 & 0.013 \\
\hline & ... a visitor of the SR & 0.288 & 330 & 0.773 & 0.032 & 0.112 & 0.032 \\
\hline
\end{tabular}

$* * \mathrm{p}<.01, * \mathrm{p}<.05$ 
The comparison of respondents using t-test for independent samples showed that there were significant differences between men and women in control group - women had more acceptance for coming people as a close personal friend (Cohen's $d=0.251$ ) and less acceptance for coming people as the co-worker / colleague (Cohen's $d=0.224)$ than men. Women from group 1 had more acceptance in terms of co-worker / colleague (Cohen's $d=0.331)$ and the visitor of the SR (Cohen's $d=0.276)$ than men. There were no differences in group 2. For the interpretation of the results, it is necessary to look at the small size of the differences between men and women.

\section{Discussion and conclusion}

The assessment of certain types of migrants (e.g. refugees, immigrants) with respect to gender differences is the subject of research by several authors (Rourke, \& Sinnot, 2006; Cowling, Anderson, \& Ferguson, 2019; Schahbassi, Huber, \& Fieder 2020). The above research studies have found that men were less accepting than women. Our research showed significant differences between men and women in control group - women had more acceptance for coming people as a close friend. Women from group 1 had more acceptance in terms of co-worker / colleague. This is consistent with previous research from Rourke and Sinnot (2006), who found that women appear to be less anti-migrant.

In the context of opinions on individual types of migrants and the hypothesis of social distance authors Sniderman, Hagendoorn and Prior (2004) point out large portion of the contemporary studies which examine the determinants of negative attitudes and social distance emphasize the role of competition on political, social, economic or cultural grounds, as a pivotal motivator of these attitudes. Within the research, respondents did not express a high level of acceptance of individual types of migrants, which is related to the findings of Cowling, Anderson and Fergusson (2019) that threat perception was identified as being the strongest correlate of negative attitudes (though, given the limited size of the literature, this claim is made with a level of caution). Threat perceptions are often the result of false beliefs, usually attributed to media influence that reinforces the threat that refugees pose to national identity and security. For this reason, it would be appropriate to examine the issue of migrants as a threat to society.

Continued work in this sphere is necessary to understand the consequences of prejudice for refugees, not only in terms of their negative impact of being targeted, but for the practical aspects such as how it impacts their treatment by host-culture members (Cowling, Anderson, \& Fergusson, 2019).

In the conditions of Slovakia, the issue of migration and individual types of migrants is promoted through the media and social media, which significantly distort and create especially sensations concerning migrants. The issue of individual types of migrants is the subject of political discussions, where there are also distortions about this issue. For this reason, we agree with the opinion of the above authors about the consequences of predecision for individual types of migrants. Given this, it is necessary to educate respondents from Slovakia in the field of migration, categorization of migrants and provide them real information that will allow them to create their own opinion and acceptance of individual types of migrants.

\section{Acknowledgements}

This research was supported by grant VEGA 2/0068/19: Attitudes towards Migrants in the Socio-psychological Context.

\section{References}

Anderson, J. R., \& Ferguson, R. (2018). Demographic and Ideological Correlates of Negative Attitudes toward Asylum Seekers: A Meta-analytic Review'. Australian Journal of Psychology, 70(1). htttps://doi.10.1111/ajpy.12162.

Ceobanu, A. M., \& Escandell, X. (2010). Comparative analyses of public attitudes toward immigrants and immigration using multinational survey data: A review of theories and research. Annual Review of Sociology, 36(1), 309-328. https://doi.org/10.1146/annurev.soc.012809.102651

Cowling, M. M., Anderson, J. R., \& Ferguson, R. (2019). Prejudice-relevant correlates of attitudes towards refugees: A meta-analysis. Journal of Refugee Studies, 32(3), 502-524. https://doi.org/10.1093/jrs/fey062

Duckitt, J. (2006). Intergroup threat and competitiveness mediate the relationships between dual dimensions of ideological attitudes and prejudice. Personality and Social Psychology Bulletin. 
Echterhoff, G., Hellmann, J. H., Back, M. D., Kärtner, J., Morina, N., \& Hertel, G. (2020). Psychological antecedents of refugee integration (PARI). Perspectives on Psychological Science: A Journal of the Association for Psychological Science, 15(4), 856-879. https://doi.org/10.1177/1745691619898838.

Findor, A., Hruška, M., Jankovská, P., \& Pobudová, M. (2021). Re-examining public opinion preferences for migrant categorizations: "Refugees" are evaluated more negatively than "migrants" and "foreigners" related to participants' direct, extended, and mass-mediated intergroup contact experiences. International Journal of Intercultural Relations: IJIR, 80, 262-273. https://doi.org/10.1016/j.ijintrel.2020.12.004

Hager, A., \& Veit, S. (2019). Attitudes toward asylum seekers: Evidence from Germany. Public Opinion Quarterly. https://doi.org/10.1093/poq/nfz023

Halperin, E., Canetti-Nisim, D., \& Pedahzur, A. (2007). Threatened by the uncontrollable: Psychological and socio-economic antecedents of social distance towards labor migrants in Israel. International Journal of Intercultural Relations: IJIR, 31(4), 459-478. https://doi.org/10.1016/j.ijintrel.2007.01.003

Mather, D. M., Jones, S. W., \& Moats, S. (2017). Improving upon Bogardus: Creating a more sensitive and dynamic social distance scale. Survey Practice, 10(4), 1-9. doi: https://dx.doi.org/10.29115/sp2017-0026

O’Rourke, K. H., \& Sinnott, R. (2006). The determinants of individual attitudes towards immigration. European Journal of Political Economy, 22(4), 838-861. https://doi.org/10.1016/j.ejpoleco.2005.10.005

Schahbasi, A., Huber, S., \& Fieder, M. (2020). Factors affecting attitudes toward migrants-An evolutionary approach. American Journal of Human Biology: The Official Journal of the Human Biology Council, 33(1), 1-13. doi: https://doi.org/10.1002/ajhb.23435

Sniderman, P. M., Hagendoorn, L., \& M. (2004). Prior Predisposing factors and situational triggers: Exclusionary reactions to immigrant minorities. American Political Science Review, 98, 35-49. https://doi.org/10.1017/S000305540400098X

The jamovi project (2020). jamovi. (Version 1.6) [Computer Software]. Retrieved from https://www.jamovi.org. 